\title{
Techniques for diagnosing viral diseases of salmonid fish
}

\author{
F. Sanz, J. Coll* \\ INIA-Sanidad Animal, Embajadores 68, E-28012 Madrid, Spain
}

\begin{abstract}
Cell culture for amplification and the techniques most used for identification of salmonid viruses - neutralization, immunofluorescence and, to a lesser extent, immunoperoxidase, complement fixation, agglutination, electron microscopy, immunodifussion or radioimmunoassay - may soon be replaced by other techniques such as enzyme immunoassays (immunodot and enzyme-linked immunosorbent assay, ELISA) and hybridization with DNA probes. It is expected that developments in monoclonal antibodies (MAbs) and amplification by the polymerase chain reaction (PCR) will increase sensitivity of enzyme immunoassays and DNA hybridizations, respectively. Some of these new methods should provide detection of the low levels of virus present in adult carriers and perhaps in eggs (although this is more complicated). Other diagnostic methods, such as measurement of virus-specific salmonid immunoglobulins (Igs) by ELISA or stimulation of immunological cellular memory by in vitro co-culture of salmonid lymphocytes with viral proteins, could also be further developed.
\end{abstract}

\section{VIRAL DISEASES OF SALMONIDS AND THEIR DIAGNOSIS}

Infectious pancreatic necrosis (IPN), viral haemorrhagic septicaemia (VHS) and infectious haematopoietic necrosis (IHN) are the major viral diseases causing severe mortalities of farm-reared salmonids. Initially found in North America, IHNV has been detected in Italy and France (Baudin 1987, Bovo et al. 1987) and is now considered a major problem for the European Community (EC 1990). Similarly, VHSV, initially found in Europe, has recently been detected in salmon on the west coast of the United States (Brunson et al. 1989, Hopper 1989).

Rapid and sensitive methods of diagnosis are critical if dissemination of the viruses causing these diseases is to be controlled, because no vaccines currently exist for their prevention. Rapid diagnosis is desirable during the acute phase of the disease, whereas highly sensitive diagnosis is necessary to detect viruses during the carrier phase of the disease.

Methods for diagnosis of viral diseases can be separated into 2 groups, those measuring the presence of the virus and those detecting the specific response of the host. To detect virus in fish it is necessary first to sample the fish population correctly, second to amplify

\footnotetext{
- Addressee for correspondence
}

the content of the sample, and third to identify the virus. To identify the virus we can measure its cytopathic effect on cell culture, proteins, nucleic acids and/or morphology. For most of these methods reagents such as polyclonal or monoclonal antibodies (Abs) and DNA probes are needed, all of which should be complementary to structural components of the virus to be identified. To detect the reaction of the host we can measure either their humoral or their cellular immunological responses.

\section{SAMPLING SALMONID POPULATIONS}

Accurate diagnosis of a viral disease depends to a large extent on the number of viruses per volume of sample. The number of viruses per volume of sample depends on the number of fish with viruses, the number of viruses per fish and the final dilution of the sample before analysis. Maximal levels of viruses reported in fish tissues undergoing natural or experimentally induced viral infections during the acute phase of the disease can vary between $10^{4}$ and $10^{8}$ tissue culture infectious dosages $\left(\mathrm{TCID}_{50}\right)^{-1}$ tissue (de Kinkelin \& Bearzotti 1981, Mulcahy et al. 1983, Hattori et al. 1984, Kimura et al. 1984, Neukirch 1984a, b, Yoshimizu \& Kimura 1985, Mulcahy \& Batts 1987, Nishimura et al. 1988, Basurco \& Coll 1989b). When sampling a popula- 
tion of salmonids a statistically significant number of fish must be collected. But it is somewhat difficult to collect a representative and random sample, especially when there is no mortality (estimated number of virus per gram of tissue $\leq 10^{3}$ ). For sampling, fish must be pooled according to age, source, species, strain, and water supply (Amos 1985). The sample size needed to detect at least one carrier fish in populations of a fixed size, and with an assumed carrier incidence, can be calculated at the $95 \%$ confidence level from the Poisson probability distribution (Amend \& Wedemeyer 1970). For instance, for a population size of 1000 salmonid fishes with a $10 \%$ incidence of carriers, 27 fish must be examined. However, to increase the probability of detecting viruses during an acute phase, one may select moribund fishes and process them separately.

To detect viruses during the carrier phase, fry, fingerling, ovarian fluid, sperm, or visceral samples may be combined into 10 -fish pools. Visceral homogenates may more effectively identify virus-carriers, but it is not practical to kill a large number of fish. In the pooling of samples mentioned above it is assumed that if one fish in the pool contains virus in excess of $10^{3} \mathrm{TCID}_{50} \mathrm{ml}^{-1}$, the virus can be detected. The possibility of detecting the virus will be increased if fewer fish per pool are used (for instance in an individual test), or if more than one carrier is present in the pooled sample.

Large numbers of individual homogenates can be made using 96 -well plates $\left(300 \mu \mathrm{l}_{\text {well }}{ }^{-1}\right)$ with 96 flattipped rods. The samples loaded in the wells are homogenized simultaneously by rotating the homogenizer against the flat-bottomed wells. Other time-saving aspects of this system include ease of sample loading and data recording, storage of samples by freezing and pipetting with multiple-pipettes (FrenchConstant \& Devonshire 1987).

\section{AMPLIFICATION OF VIRAL CONTENT OF SAMPLES}

Once sampling has been optimized the viral content of the homogenate requires amplification by inoculation into cell culture (Wolf \& Mann 1980, Lannan et al. 1984, Amos 1985). Currently the most sensitive method for detection of IPNV involves co-cultivation of cell lines with kidney cells or leucocytes from the test fish (Agius et al. 1982, Ahne \& Thomsen 1986). However, to avoid inhibition by the tissue extracts, the tissues should be diluted 100-fold or more (Dixon 1987). New developments are expected in this area due to the possibility of amplification of viral genomes by the PCR (polymerase chain reaction) technique. The viral DNA amplification can take place in a few hours and from a larger volume of sample (since by nucleic acid extrac- tion, samples can be concentrated to very small final volumes). In addition it can be made highly specific to the virus by selecting sequence-specific primers (see below).

\section{ANTIBODIES TO VIRAL PROTEINS}

To identify the presence of viral proteins by immunological methods specific Abs should be prepared. These can be either polyclonal antibodies (PAbs) or monoclonal antibodies (MAbs). Fig. 1 shows the general schemes followed by most of the immunological methods.

There are no significant differences in the protein content among different VHSV isolates (Basurco \& Coll 1989a), although an $N_{x}$ protein has been found in VHSV nucleocapsids that was not in similar IHNV preparations, which could allow for differential diagnosis in some cases (Basurco et al. 1991). Viral protein content is a measure of the number of virions; $1 \mathrm{ng}$ of rhabdoviral protein represents $10^{7}$ virus particles (Hsu \& Leong 1985), but because the particle-to-infectivity ratio is about $1000: 1$, that will only mean about $10^{4}$ infective viruses. Theoretically the immunological methods to detect these amounts provide an advantage over the cell culture methods. Immunological methods measure both viral proteins, which may or may not be incorporated into a viral particle, and viral particles which may or may not be infective. To date however, none of the immunological assays has proven to be more sensitive than virus isolation by cell culture techniques.

Workers have used a wide variety of inoculation programs to obtain PAbs in rabbits for VHSV and IHNV, but the neutralization titres (reciprocal of last dilution to give neutralization) obtained have generally

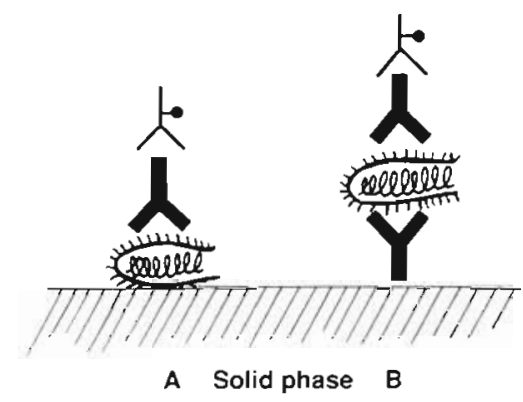

Fig. 1. Scheme of immunological virus detecting methods. The solid phase can be infected cells (immunofluorescence or immunoperoxidase method), nitrocellulose membranes (immunodot) or microtitre wells (ELISA). (A) Indirect methods: (B) sandwich methods. Y-shaped symbols represent specific Abs (PAbs or MAbs); inverted Y-shaped symbols with dots connected to them represent $A b$ labeled with fluorescence or with peroxidase. The specific anti-virus Abs could also be labeled to simplify the method 
ranged from $\leq 10^{2}$ to $10^{4}$ (Habashi et al. 1975, Hill et al. 1981). In contrast, neutralization titres of $10^{6}$ are usually obtained against IPNV. Antisera containing neutralizing $\mathrm{Abs}$ to salmonid viruses, produced by immunizing rabbits, contain antiviral Abs, but also Abs either to the cell line used to obtain the virus or to the fish tissue components. Attempts to absorb out these Abs have not been entirely successful, although some procedures work well, e.g. in vivo adsorption. Alternatively, 2 different cell lines could be used to obtain the virus and to perform the diagnosis, although this does not always solve the problem.

Before MAbs became available, most immunoassays used the Ig (immunoglobulin) fraction of an immune serum to prepare the reagents. However, the best immune sera contain only $10 \%$ specific anti-virus $\mathrm{Ab}$, which means a 10-fold decrease in specific activity and some background and/or cross-reactivity problems. Antigen-affinity-purified Abs are free of the problems mentioned above but they might be difficult to obtain because of the large amounts of purified virus needed to make the affinity columns. MAbs would probably be the best alternative since they have already been obtained and characterized against IPNV (CaswellReno et al. 1986, Wolski et al. 1986, Domínguez et al. 1990), VHSV (Lorenzen et al. 1988, Mourton et al. 1990, Sanz et al. unpubl.) and IHNV (Schultz et al. 1985, Winton et al. 1988, Ristow \& Arnzen 1991).

\section{TECHNIQUES FOR IDENTIFICATION OF VIRAL PROTEINS}

\section{Neutralization}

This method identifies the virus by neutralizing its in vitro infectivity (Deuter \& Enzmann 1986). By using PAbs obtained in rabbits as neutralizing reagents it was possible to differentiate 3 IPNV serotypes, although a classification into 2 serogroups with 9 serotypes in the first serogroup has been proposed (Hill \& Way 1983). On the one hand, however, important antigenic differences could be observed even within the same serogroup (Hill \& Way 1980, McDonald \& Gower 1981, Nicholson \& Pochebit 1981, Okamoto et al. 1983); but on the other hand, substantial antigenic relationships exist among the strains of IPNV when examined by immunodiffusion or immunofluorescence (Ishiguro et al. 1984). By neutralization it was also possible to differentiate 3 VHSV serotypes (Le Berre et al. 1977, Ahne et al. 1986), but no cross-neutralization between IHNV and VHSV has yet been demonstrated (McAllister et al. 1974), nor have different IHNV serotypes been described (Engelking et al. 1991). Neutralizing MAbs have been difficult to obtain for
IPNV (Dominguez et al. 1990), VHSV (Lorenzen et al. 1990, Sanz et al. unpubl.) and IHNV (Winton et al. 1988, Ristow \& Arnzen 1991). Only a few neutralizing MAbs have been described, and their use has not been yet reported in clinical diagnosis. Day-to-day variation (Olesen \& Vestergaard-Jørgensen 1986), inhibition of infectivity by the fish tissue extracts (Dixon 1987) and the time-consuming, labour-intensive character of the neutralization test (Ghittino et al. 1980, McIntosh et al. 1980) necessitate the need to look for alternatives.

\section{Immunofluorescence}

This technique has been extensively used for detection of viral antigens in cell cultures and fish tissues (Piper et al. 1973, Meier \& Vestergaard-Jørgensen 1975, Menezes 1977, Swanson \& Gillespie 1981, Ahne et al. 1986). To detect virus by immunofluorescence, coverslip cultures are infected and fixed at the beginning of the cytopathic effect. Half of the coverslip can be used for reaction with anti-VHSV and half with antiIPNV. In cultures infected with 10 viruses per cell, specific anti-virus fluorescence was observable after $8 \mathrm{~h}$, but with 1 virus per cell up to $16 \mathrm{~h}$ were needed (Vestergaard-Jørgensen 1968, 1972, 1974). The need for fresh, quickly frozen fish tissues is a disadvantage of this technique. Furthermore, autofluorescence of fish tissues and cross-reacting PAbs can interfere with interpretation of the results (Ahne 1981). Though adsorption of the PAbs with fish tissue homogenates removed most of their non-specific staining, the virus titres found in the tissues of VHSV carriers were not always associated with the number of fluorescent cells (Vestergaard-Jørgensen \& Meyling 1972). It remains to be seen whether or not the use of MAbs for fluorescence (Fig. 2) will increase the sensitivity (Table 1) of this technique (Wolski et al. 1986, Winton et al. 1988, Lehmann et al. 1990, Arnzen et al. 1991).

\section{Immunoperoxidase}

The immunoperoxidase technique provides some advantages over immunofluorescence, such as elimination of background staining, use of an ordinary light microscope and the possibility of keeping the results for a long time. The immunoperoxidase method may be considered to be slightly more sensitive than immunofluorescence because the virus antigen could be detected earlier in cell culture. However, only when the virus titres of frozen samples of kidney and spleen from infected fish were $>10^{8}$ TCID $_{50} \mathrm{~g}^{-1}$ did they show a positive reaction (Faisal \& Ahne 1980). The need for removal of endogenous peroxidase(s) adds one more 


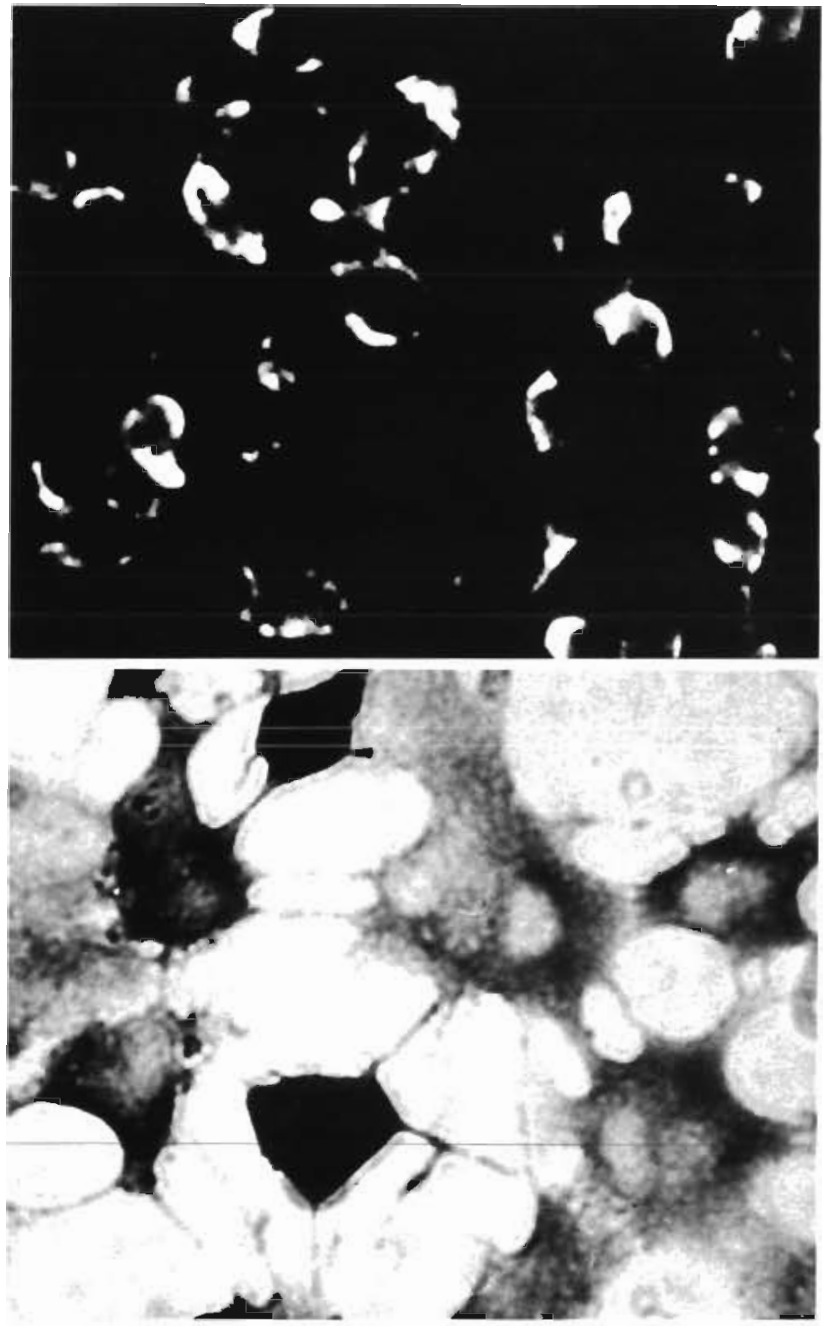

Fig. 2. VHSV-infected epithelium papillosum carp (EPC) cells stained by immunofluorescence (upper panel) with anti-N VHSV MAb, or by immunoperoxidase (lower panel) with antiN VHSV MAb labeled with horseradish peroxidase (MAbs described in Sanz \& Coll 1992 step to this technique. Both immunofluorescence and immunoperoxidase require either cell culture techniques or sectioning of infected tissues. Because of their low sensitivity and because of the need to process each sample one at a time they are not very useful for detecting carriers (Nicholson \& Henchal 1978). It remains to be seen whether the use of MAbs can increase the sensitivity of this technique (Fig. 2).

\section{Agglutination}

Simple, specific, cheap, easily semiquantified and suitable for use in the field, this technique requires no special apparatus. The diagnostic results, however must be confirmed by other techniques due to the high incidence of false positives (Yoshimizu \& Kimura 1985). Cultures of fish cells infected with presumptive viruses are fixed and then Staphylococcus aureus Cowan strain A (binds IgG) sensitized with anti-virus PAbs is added washed and the whole preparation stained. The average number of bacteria attached per cell varies between 0.5 in non-infected controls to 10 in infected cultures (Bragg \& Combrimk 1987). The fish tissue samples could also be homogenized, centrifuged, the supernatant mixed with the anti-virus sensitized bacteria and agglutination observed. Under solid-phase immuno-electron microscopy, the agglutinated bacteria sensitized with anti-virus $\mathrm{Ab}$ showed virus at their surfaces (Yoshimizu \& Kimura 1985). The minimum titre of IPNV necessary to show a positive reaction was $10^{6} \mathrm{TCID}_{50} \mathrm{ml}^{-1}$ in cell culture (Kimura et al. 1984) and $10^{3} \mathrm{TCID}_{50} \mathrm{~g}^{-1}$ in trout undergoing the disease (Table 1). The IPNV antigen could be detected after an 80 -fold dilution of samples by increasing the time of the agglutination reaction from 30 to 90 min (Kimura et al. 1984). Agglutination using MAbs or the highly reproducible latex techniques has not yet been applied to the virus of salmonids.

Table 1. Comparison of sensitivity of enzyme-immuno-indirect methods. Sensitivity was defined as the minimal amount of virus that produced a significant difference to the control. PV: Purified virus; CCS: cell culture supernatant; TE: tissue extract P: polyclonal; M: monoclonal; F: fluorescence; A: agglutination; F.P. false positives, -: not determined

\begin{tabular}{|llccccc}
\hline Virus & Ab & Method & $\begin{array}{c}\mathrm{PV} \\
\left(\mathrm{ng} \mathrm{ml}^{-1}\right)\end{array}$ & $\begin{array}{c}\mathrm{CCS} \\
\left(\mathrm{TCID}_{50} \mathrm{ml}^{-1}\right)\end{array}$ & $\begin{array}{c}\text { TE } \\
\left(\mathrm{TCID}_{50} \mathrm{~g}^{-1}\right)\end{array}$ & Source \\
\hline IPN & $\mathrm{P}$ & $\mathrm{F}$ & - & $10^{5}$ & - & Swanson \& Gillespie (1981) \\
& $\mathrm{P}$ & $\mathrm{A}$ & - & $10^{3}$ & $10^{3}$ & Kimura et al. (1984) \\
& $\mathrm{P}$ & Dot & 85 & $10^{5}$ & - & McAllister \& Schill (1986) \\
& $\mathrm{M}$ & Dot & 20 & $10^{5}$ & - & Hsu et al. (1989) \\
VHS & $\mathrm{P}$ & Dot & 400 & $10^{5}$ & - & McAllister \& Schill (1986) \\
IHN & $\mathrm{P}$ & Dot & 400 & $10^{5}$ & - & Mc Allister \& Schill (1986) \\
& $\mathrm{P}$ & Dot & 1000 & - & - & Hsu \& Leong (1985) \\
& $\mathrm{M}$ & Dot & 550 & $10^{4}$ & F.P. & Schultz et al. (1989) \\
\hline
\end{tabular}




\section{Enzyme immunoassay (ELISA)}

ELISA has recently gained acceptance as a rapid, specific and sensitive means of detecting and identifying salmonid viruses (Dixon 1985). The major advantages of ELISA are rapid processing of large numbers of samples with the possibility of automation, and reproducibility of the large-scale production (Coll 1991a).

In early reports on the use of ELISA for IPNV detection with PAbs, sensitivity levels of $10^{5} \mathrm{TCID}_{50} \mathrm{ml}^{-1}$ of culture fluid and of $10^{4}$ to $10^{7} \mathrm{TCID}_{50} \mathrm{~g}^{-1}$ of infected trout were given (Nicholson \& Caswell 1982, Dixon \& Hill 1983). Viral antigens could be detected 24 h before the cytopathic effect in cell culture. The sensitivity was about $10 \mathrm{ng}$ of purified virus $\mathrm{ml}^{-1}$ if no fry extract was added and $100 \mathrm{ng}$ of purified virus $\mathrm{ml}^{-1}$ when fry extract was added. Moribund fry from a natural infection with $90 \%$ mortality showed a high value by ELISA. A sensitivity increase was claimed by Hattori et al. (1984) to allow detection of $10^{4} \mathrm{TCID}_{50} \mathrm{ml}^{-1}$ and by Rodak et al. (1988) to allow detection of $10^{3}$ TCID $_{50}$ $\mathrm{ml}^{-1}$. Dominguez et al. (1990) described the use of MAbs with similar detection levels corresponding to 10 $\mathrm{ng}$ of purified virus $\mathrm{ml}^{-1}$. Rather than on new methodological approaches, however, these differences seem to depend on the quality of the Abs, the amount of $\mathrm{Ab}$ bound to the solid phase or the presence of variable concentrations of non-infective viral particles in the samples tested (Table 2). Acute phases might still be measured by this technique but its sensitivity is not yet sufficient to detect carriers (Table 2). Rapid serotyping of IPNV has also been recently described with the help of serotype-specific MAbs by ELISA (Babin et al. 1990, Domínguez et al. 1991).

The ELISA technique using PAbs has also been adapted to the salmonid rhabdoviruses, IHNV (Dixon \&
Hill 1984) and VHSV (Way \& Dixon 1988). Viruses could be detected in cell culture before any cytopathic effect and both assays were specific for their respective viruses. Results were obtained in under $2 \mathrm{~h}$, but sensitivity was still a problem (Table 2). A sensitivity of 1 or $0.2 \mathrm{ng}$ $\mathrm{ml}^{-1}$ (Table 2) has been found for VHSV $\mathrm{F}_{1}$ by using MAbs against the G proteins (Mourton et al. 1990) or for all serotypes of VHSV by using MAbs against the $N$ proteins (Fig. 3; Sanz \& Coll 1992). The use of anti-Nprotein MAbs of high titre allowed the recognition of all the serotypes of VHSV, whereas the use of high-ionicstrength buffers disrupting the nucleocapsids increased the sensitivity about 100-fold (Sanz \& Coll 1990, 1991, 1992). The use of 2 non-overlapping MAbs has simplified the procedure to a 1-step assay which unexpectedly added a further 10-fold increase in the sensitivity. The high sensitivity obtained correctly detected infection of fingerling trout in the laboratory (Fig. 3).

Despite high numbers of MAbs developed against the G or the N proteins of IHNV (Ristow \& Arnzen 1989, 1991), ELISA in its present state has low sensitivity for detecting IHNV and is limited to type 2 IHNV (S. Ristow pers. comm.). A different choice of new MAbs, a known mixture of MAbs for the second $\mathrm{Ab}$, higher-titre MAbs, high-ionic-strength buffers and/or other MAbs isotypes must be used to obtain higher ELISA sensitivity. Furthermore, it is obvious that preparation of an ELISA for all the IHNV types isolated in the United States and Europe will take a lot more work.

The increase in sensitivity of solid-phase ELISA is dependent, among other variables, on the amount of Ab binding to the solid phase. This in turn is limited by the fraction of specific Abs present in the Igs preparation and by the capacity of the well surface to bind. Assuming a maximum adsorption to polyestyrene of 1.5

Table 2. Comparison of sensitivity of sandwich ELISA. Sensitivity was defined as the minimal amount of virus that produced double than the background absorbance. PV: Purified virus; CCS: cell culture supernatant; TE: tissue extract; P: polyclonal; M: monoclonal; -: not determined

\begin{tabular}{|c|c|c|c|c|c|}
\hline Virus & $\begin{array}{c}A b^{a} \\
\left(\mu \mathrm{m} \text { well }^{-1}\right)\end{array}$ & $\begin{array}{c}\mathrm{PV} \\
\left(\mathrm{ng} \mathrm{ml}^{-1}\right)\end{array}$ & $\begin{array}{c}\mathrm{CCS} \\
\left(\mathrm{TCID}_{50} \mathrm{ml}^{-1}\right)\end{array}$ & $\begin{array}{c}\operatorname{TE}^{\mathrm{b}} \\
\left(\mathrm{TCID}_{50} \mathrm{~g}^{-1}\right)\end{array}$ & Source \\
\hline IPN & $\begin{array}{lr}\mathrm{P}, & 0.5 \\
\mathrm{P}_{1} & 100.0 \\
\mathrm{P}, & 1.0 \\
\mathrm{M}, & 0.2\end{array}$ & $\begin{array}{r}10 \\
50 \\
- \\
10\end{array}$ & $\begin{array}{l}10^{5} \\
10^{4} \\
10^{3} \\
10^{3}\end{array}$ & $\begin{array}{c}10^{4} \\
10^{4} \\
- \\
-\end{array}$ & $\begin{array}{l}\text { Dixon \& Hill (1983) } \\
\text { Hattori et al. (1984) } \\
\text { Rodak et al. (1988) } \\
\text { Domínguez et al (1990) }\end{array}$ \\
\hline VHS & 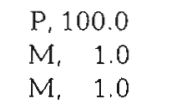 & $\begin{array}{l}- \\
1 \\
0.2\end{array}$ & $\begin{array}{l}10^{5} \\
10^{5} \\
10^{3}\end{array}$ & $\begin{array}{c}10^{5} \\
- \\
10^{3}\end{array}$ & $\begin{array}{l}\text { Way \& Dixon (1988) } \\
\text { Mourton et al. }(1990) \\
\text { Sanz \& Coll }(1991,1992)\end{array}$ \\
\hline IHN & $\begin{array}{l}P, 100.0 \\
P, 100.0\end{array}$ & $\begin{array}{l}- \\
-\end{array}$ & $\begin{array}{l}10^{5} \\
10^{6}\end{array}$ & $\begin{array}{l}10^{6} \\
10^{6}\end{array}$ & $\begin{array}{l}\text { Dixon \& Hill (1984) } \\
\text { Way \& Dixon (1988) }\end{array}$ \\
\hline
\end{tabular}




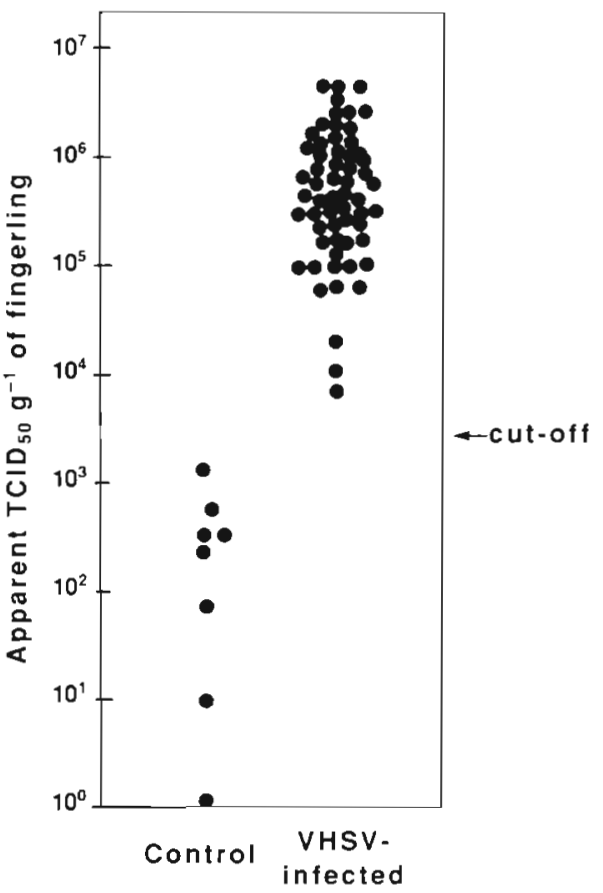

Fig. 3. Onchorynchus mykiss. Apparent VHSV concentrations obtained by ELISA in fingerling trout samples from control and dead VHSV-infected fish. Apparent VHSV concentrations were calculated from standard curves made with VHSV tested in cell culture by $\mathrm{TCID}_{50}$. Trout fingerlings $(0.2$ to $\left.1 \mathrm{~g} \mathrm{fish}{ }^{-1}\right)$ were infected with VHSV $\left(10^{6} \mathrm{TCID}_{50} \mathrm{ml}^{-1}, 2 \mathrm{~h}\right.$, $9^{\circ} \mathrm{C}$ ). Mortality after $20 \mathrm{~d}$ was $77.6 \%$. Dead fish were homogenized in $2 \mathrm{ml}$ of tissue culture media and assayed by ELISA using 2 non-competitive anti-VHSV nucleoprotein MAbs in high-ionic-strengh buffer to disrupt the viruses (from Sanz \& Coll 1992)

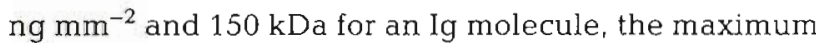
attainable concentration for an antigen-affinitypurified MAb is about $10^{-8} \mathrm{M}\left(1 \mu \mathrm{g}\right.$ well $\left.{ }^{-1}\right)$. For affinitypurified PAbs, immune sera or post-infection sera, about 3,10 or 100 times less specific $\mathrm{Ab}$ will be bound. The use of MAbs and of new microtiter plates with nitrocellulose bottoms may also help to increase sensitivity, since nitrocellulose binds about 50-fold more protein than does polystyrene.

Table 3 shows an example of some preliminary results from diagnostic work in Spain using sandwich ELISA based on MAbs to detect IPNV and VHSV directly in fish tissue homogenates. These techniques may be used in routine diagnoses to simplify and speed up the assays.

\section{Immunodot}

Other techniques either require instruments or complicated manipulations, or have low sensivitity, or are time-consuming (Hsu et al. 1989, Schultz et al. 1989). Those reasons have been invoked in favour of the more simple, speedy and sensitive immunodot technique for detection of $20 \mathrm{ng} \mathrm{ml}^{-1}$ or $10^{5} \mathrm{TCID}_{50} \mathrm{ml}^{-1}$ of IPNV
(Table 1). In the immunodot assay, the viral proteins are bound to a solid-phase matrix (usually made of nitrocellulose) of high binding capacity and therefore high sensitivity, and are detected by their immunoenzymatic reactivity. The results can be interpreted by visual inspection as negative or positive (coloured). Semiquantification could be achieved by reflectance densitometry, since under $1000 \mathrm{ng} \mathrm{ml}^{-1}$ the quantity of the viral protein showed a linear relationship with the optical density. However, because of the precipitable substrates needed for immunodot, the final sensitivity is of the same order of magnitude as for ELISA. An advantage of immunodot over ELISA is that the results in the immunodot can be kept dried as a record or for later measurement (Hsu et al. 1989).

By using PAbs with neutralization titres of $3 \times 10^{6}$ (IPNV) or 500 (VHSV and IHNV), the immunodot assay detected $0.85 \mathrm{ng}$ of IPNV or $4 \mathrm{ng}$ of VHSV and IHNV (Table 1), which represented about $10^{3} \mathrm{TCID}_{50}$ (McAllister \& Schill 1986). Heterologous reactions of the PAbs were eliminated by adsorption with fetal calf serum and extracts from the cells were used to amplify the virus. Immunodot sensitivity could have been increased by increasing sample volume, but when used to detect virus in fish homogenates, the nitrocellulose was clogged by their higher protein content (McAllister $\&$ Schill 1986). Passage of the sample through cell culture both amplifies the viruses and decreases their protein content, therefore increasing sensitivity. Less than $1 \mathrm{ng}$ of IHNV protein was detected by radiolabelling of virus-specific proteins (Hsu \& Leong 1985), but the immunological detection offered advantages in cost, accuracy, speed and, in the case of immunoenzymatic reagents, stability and ease of handling. Furthermore, the immunological methods also yielded information about the relatedness of different isolates. MAbs have been developed and used in several investigations (Caswell-Reno et al. 1989, Lilipun et al. 1989, Babin et al. 1991) for antigenic characterization and improved diagnosis of IPNV with the immunodot test. Schultz et al. (1989) developed an immunodot assay for detection of IHNV by using MAbs that detected $10^{2} \mathrm{TCID}_{50}$. Because the immunodot detects binding Abs rather than neutralizing Abs, identification of the 3 serotypes of VHSV was also made possible by using a unique antiserum to one of them (McAllister \& Owens 1987).

Finally, if a sandwich dot could be developed, this technique could be used as a field test using plastic sticks.

\section{TECHNIQUES FOR IDENTIFICATION OF VIRAL GENOMES}

Genomic divergence among IPNV (RNA genome) serotypes have been studied by c-DNA hybridization (McDonald \& Gower 1981), but there have been few 
Table 3. Examples of results from diagnostic work using sandwich ELISA (authors unpubl.). Fingerling fish viscera or adult fish kidney were pooled in groups of 5 to $10 \mathrm{fish}$, homogenized at $10 \% \mathrm{w} / \mathrm{v}$ and assayed by cell culture techniques as described in Jimenez et al. (1988) and Basurco \& Coll (1989). Cell culture results were read after 2 consecutive passes in EPC and/or RTG-2 fish cell lines, $7 \mathrm{~d}$ per pass. The ELISA was performed directly in the homogenate as described for the 1 -step method (Sanz \& Coll 1991a, b). The ELISA of IPNV performed in the supernatant from the first cell culture pass gave the same results. SVC: Spring viraemia of carp

\begin{tabular}{|c|c|c|c|c|c|c|c|}
\hline \multirow{2}{*}{ Species } & \multirow{2}{*}{$\begin{array}{c}\text { Fish weight } \\
\text { (g) }\end{array}$} & \multirow[t]{2}{*}{ Mortality } & \multirow{2}{*}{$\begin{array}{c}\text { Arrival } \\
\text { in laboratory }\end{array}$} & \multirow{2}{*}{$\begin{array}{c}\text { Cell } \\
\text { culture }\end{array}$} & \multicolumn{2}{|c|}{ ELISA } & \multirow{2}{*}{ Diagnosis } \\
\hline & & & & & IPN & VHS & \\
\hline Onchorynchus mykiss & $(1-3)$ & Yes & Alive & + & + & - & IPNV \\
\hline Onchorynchus mykiss & $(1-3)$ & Yes & Alive & + & + & - & IPNV \\
\hline Onchorynchus mykiss & $(1-3)$ & Yes & Alive & + & + & - & IPNV \\
\hline Onchorynchus mykiss & $(1-3)$ & Yes & Refrigerated & - & - & - & Streptococcus \\
\hline Onchorynchus mykiss & $(1-3)$ & Yes & Alive & - & - & - & Unidentified \\
\hline Onchorynchus mykiss & $(50-100)$ & Yes & Alive & + & - & + & VHSV \\
\hline Onchorynchus mykiss & $(50-100)$ & Yes & Alive & + & - & + & VHSV \\
\hline Onchorynchus mykiss & $(50-100)$ & Yes & Refrigerated & - & - & - & Water quality \\
\hline Onchorynchus mykiss & $(50-100)$ & Yes & Refrigerated & - & -. & - & Streptococcus \\
\hline Onchorynchus mykiss & $(50-100)$ & No & Frozen & - & - & - & Healthy \\
\hline Onchorynchus mykiss & $(50-100)$ & No & Refrigerated & - & - & $\rightarrow$ & Healthy \\
\hline Onchorynchus mykiss & $(50-100)$ & No & Alive & - & - & - & Healthy \\
\hline Salmo salar & $(100-200)$ & No & Frozen & - & - & - & Healthy \\
\hline Salmo salar & $(100-200)$ & No & Frozen & - & - & - & Healthy \\
\hline Barbus graellsi & $(50-100)$ & Yes & Refrigerated & - & - & - & Water quality \\
\hline Barbus graellsi & $(50-100)$ & Yes & Refrigerated & - & - & - & Water quality \\
\hline Sparas auratus & $(3-10)$ & No & Alive & - & - & - & Healthy \\
\hline Sparas auratus & $(3-10)$ & No & Alive & - & - & - & Healthy \\
\hline Sparas auratus & $(3-10)$ & No & Alive & - & - & - & Healthy \\
\hline Cyprinus carpus & $(500-1000)$ & Yes & Refrigerated & + & - & - & SVC \\
\hline
\end{tabular}

reports to date on the use of DNA probes to detect salmonid viral genomes (Winton 1991). Plasmids containing IPNV (Duncan et al. 1987), IHNV (Gilmore \& Leong 1988) and VHSV (Bernard et al. 1990) viral sequences have been already constructed. Because the DNA hybridization procedures are not significantly more sensitive than ELISA (Enzmann et al. 1981) the practical use of these techniques will probably be linked to the development of prior genome amplification by the PCR technique (Sobrino et al. 1989). The partial sequences of the genomes of IPNV, VHSV and IHNV have been reported and can be used to select the appropriate specific primers for the amplification by using computer programs (Lowe et al. 1990). The selective amplification of viral genomes by the use of appropriate sequence-specific primers, and both the non-radioactive detection methods and automated hybridization, will probably solve the problems of sensitivity and of processing large numbers of samples, respectively, in detecting virus from carrier-salmonids and/or from eggs (Coll 1991b).

A biotinylated DNA probe for rapid detection of IHNV has been designed to detect the $N$ messenger RNA of IHNV. A 30-nucleotide target site for the probe was chosen by computer search of the published sequence of the $\mathrm{N}$ gene of IHNV. A synthetic nucleotide complementary to this sequence was obtained, coupled to biotin and detected with streptavidin-peroxidase conjugate. All IHNV electropherotypes were detected, but no other rhabdovirus. The probe could detect infection of cell cultures after $24 \mathrm{~h}$ but was not tested in fish tissues (Winton 1991). Arakawa et al. (1990) used PCR to amplify a portion of the $\mathrm{N}$ gene of IHNV. The primers spanned a 252 nucleotide sequence to be used with the biotinilated probe described above. The PCR was able to amplify RNA extracted from IHNV-infected trout to levels that were easily detected with the biotinilated probe. Primers to amplify segments of sequences of IHNV (522 bp), VHSV (408 bp) and IPNV $(339 \mathrm{bp}$ ) have also been used to detect viruses in cell culture and to differentiate them by the molecular weight of the amplified segment after agarose electrophoresis of the amplified sample (McAllister, Schill, Owens \& Hodge pers. comm.).

A different approach uses the incorporation of a biotin-nucleotide during PCR amplification of a segment of VHSV defined by 2 primers in the $M_{1}$ protein (Estepa \& Coll unpubl.). The amplified product is hybridized to a plasmid probe immobilized on solid-phase microtitre 96-well plates (HYBRELISA). The application of the highly stable reagents previously developed and optimized for ELISA (e.g. a 2 yr stable dilution buffer at room temperature), addition of merthiolate to the hybridization buffer to increase their stability, addition of formamide to decrease the hybridization temperature, addition of phenol red to allow visualization 


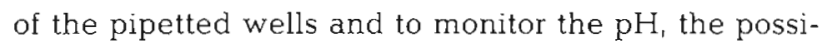
bility of using microtitre plates divided in rows that adapt the number of assays to the daily variable number of samples, and low-background substrate buffer make this hybridization technique easily scalable, highly reproducible, and available for diagnostic testing of a large number of samples (Coll 1991b). The routine application of this method in the laboratory is still under development.

\section{TECHNIQUES FOR MEASUREMENT OF SALMONID RESPONSES}

\section{Measurement of salmonid antibody responses}

Total serum levels of tetrameric Igs from adult rainbow trout surviving IPNV infection were 5- to 10-fold higher than those from adult rainbow trout from IPNVfree farms (Sánchez \& Coll 1989, Sánchez et al. 1989). Titres of neutralizing Abs to IPNV were measured in serum from rainbow trout reared in IPNV-free environments (titres of 80 to 4000 ) as well as from trout exposed to IPNV (titres of 300 to 3000 ). In artificially immunized trout, the neutralizing Ab titre increased from 400 to 2800 after the virus injections (Vestergaard-Jørgensen 1973). However, from the data mentioned above we can conclude that it will be very difficult to find a diagnostic value for trout anti-viral Abs.

Trout serum with complement activity (Dorson \& Torchy 1979, Dorson et al. 1979) should be used for detection of neutralizing Abs to VHSV (Olesen \& Vestergaard-Jørgensen 1986). Maximal titres of neutralization of 10000 were found weeks after infection, with about $40 \%$ of the surviving trout still showing titres of 160 one year after infection. Results from a survey of sera collected in farms with previous histories of VHS showed $25 \%$ of the trout having titres $>160$ (ranging from 20 to 1500) (Olesen \& Vestergaard-Jørgensen 1986).

In the USA, mortality due to IHN ranges from 20 to $30 \%$ of the fry raised. Mortality during epizootic events can exceed $90 \%$ of the infected fish (Shors \& Winston 1989). During the test of eggs from spawning females, neutralizing Abs for IHNV have been identified by immunoblotting and neutralization (Shors \& Winston 1989). This raises the possibility of salmonid parental passive immunity of the offspring to viruses. Parental passive immunity will explain why fish will be healthy until fingerling stage and then when immunity decays the fish will be struck by an epizootic, but that could not be the explanation in the case where IPNV and/or other viruses were isolated from the eggs of trout (Fijan \& Giorgetti 1978). More experimental evidence is needed before conclusions can be drawn from these few reports

Indirect ELISA has also been used to detect salmonid
Ab responses to viral infection, but, whereas detection of mouse or rabbit Abs against VHSV required only 2 to $5 \mathrm{ng}$ of viral protein well ${ }^{-1}$, detection of trout Abs required at least 200 to $500 \mathrm{ng}$ well ${ }^{-1}$ (Cossarini-Dunier 1985). Trout Igs have both a low affinity towards the virus and a high affinity to plastic surfaces, therefore increasing the background of ELISA and giving rise to false positives. To define the cut-off between true negatives and positives, large numbers of fish with no previous history of viral infections should be used. Recently, to circumvent the problems mentioned above, a VHSV capture ELISA has been described to measure VHSV-specific trout Ig. At least in this case, the ELISA proved to be more sensitive, and it is always less time- and material-consuming than either immunofluorescence or neutralization. Antibody to VHSV was found in $54 \%$ of fish from previously infected trout farms (Olesen et al. 1991).

Other alternative ways to measure anti-VHSV trout Abs, like trout Ig capture with MAbs, should be studied further (Sánchez et al. 1990, 1991, Thuvander et al. 1990).

\section{Measurement of salmonid cellular responses}

Investigations of salmonid cellular responses to viral infections are scarce. Lymphocyte stimulation was shown in trout surviving the VHSV disease (Chilmonczyk 1977, 1978, Estepa et al. 1991a), and IPNV carrier lymphocytes have been demonstrated by immunofluorescence (Enzmann 1981) and flow cytometry (Saint-Jean et al. 1991), even though the corresponding circulating Abs were only detected in low levels (Vestergaard-Jørgensen 1971). Lymphocyte virus carriers could possibly be detected by cytofluorometry, but to date this technique has been applied only to study healthy fish lymphocytes (Deluca et al. 1983, Evans et al. 1987). The effect of in vitro VHSV infection of salmonid lymphocytes as well as the responses of the lymphocytes isolated from carrier salmonids to inactivated viruses and to purified VHSV proteins are presently being studied (Estepa \& Coll 1991, 1992, Estepa et al. 1991b). Leucocytes from trout kidney surviving the VHS disease were capable of proliferation (as measured by thymidine incorporation and the fibrinclot technique) only when purified proteins $\mathrm{N}$ or $\mathrm{G}$ from VHSV were added to their in vitro cultures. The response lasted for at least 1 yr (Estepa et al. 1991a). Whether this method could be applied to detect carriers as a routine diagnostic procedure remains to be seen.

\section{CONCLUSIONS}

Most viral diagnoses continue to be obtained through isolation of virus in monolayers of fish cells, followed by neutralization of the virus with PAbs. Unfortunately, 
Table 4. Comparison among different techniques of possible usefulness in diagnosing viral diseases of salmonids. Sensitivity classified as high ( 1 virus); medium ( $10^{3}$ to $10^{4}$ viruses) and low ( $\geq 10^{4}$ viruses). Speed classified as fast (hours), rapid (days) and slow (weeks). Specificity classified as high (low percentage of false positives) and medium (high percentage of false positives). 'Field' indicates the possibility of using the assay in the field, thus affecting the simplicity of the technique. The possibility of automation allows processing of a large number of samples. CC indicates that cell cultures are required, an additional technical difficulty for the assay

\begin{tabular}{|c|c|c|c|c|c|c|}
\hline \multirow[t]{2}{*}{ Technique } & \multicolumn{6}{|c|}{ Characteristics } \\
\hline & Sensitivity & Speed & Specificity & Field & Automation & $\mathrm{CC}$ \\
\hline \multicolumn{7}{|l|}{ Virus } \\
\hline Neutralization & High & Low & High & No & No & Yes \\
\hline Immunofluorescence & Medium & Fast & Medium & No & No & Yes \\
\hline Agglutination & Low & Fast & Medium & Yes & No & Yes \\
\hline Immunodot & Medium & Fast & High & No & No & Yes \\
\hline ELISA (MAbs) & Medium & Fast & High & Yes & Yes & No \\
\hline PCR & High & Rapid & High & No & Yes & No \\
\hline \multicolumn{7}{|l|}{ Host responses } \\
\hline Antibodies ELISA & Medium & Fast & Medium & Yes & Yes & No \\
\hline Lymphocytes & High & Slow & High & No & No & Yes \\
\hline
\end{tabular}

this is also the most time-consuming technique (Table 4). Immunofluorescence has provided a rapid yet specific alternative: however, it is less sensitive and therefore valid only during the acute phase of infection. Other techniques such as immunoperoxidase, electron microscopy (Zwillenberg et al. 1965, Cohen \& Lenoir 1974, Olberding \& Frost 1975, Amlacher et al. 1980), counter immunoelectrophoresis (Dear \& Elazhary 1983), complement fixation (Finlay \& Hill 1975), agglutination and radioimmunoassay, have not gained wide acceptance.

The detection of virus in tissue homogenates by sandwich ELISA with MAbs is an alternative technique growing in importance, although again limited to the acute phase of infection. The immunodot technique is a rapid, sensitive and quantitative method for diagnosis of virus, but in contrast to ELISA it can only be used in infected tissue culture lysates. ELISA is preferable for rapid testing of a large number of samples from disease outbreaks (Table 3) or as a screening method in older fish if its sensitivity can be increased (Coll 1989). Ideally, a panel of different ELISA systems (IPNV, VHSV and IHNV) could be used to provide both rapid detection and identification during disease.

To be able to screen salmonid virus-carriers, however, highly sensitive methods are still in development. These include accurate measurement of specific salmonid antiviral Igs by ELISA, estimation of cell memory by in vitro Co-culture of salmonid lymphocytes with isolated viral proteins, and amplification and detection of viral genomes by the PCR technique and HYBRELISA, respectively.

Acknowledgements. Thanks are given to Dr Bernardo Basurco for help with the bibliography. This work was supported by Instituto Nacional de Investigaciones Agrarias Grant 8568 from the Ministerio de Agricultura of Spain.

\section{LITERATURE CITED}

Agius, A., Margumuiryo, M., Johnson, H. R., Smajl, D. A. (1982). A more sensitive technique for isolating IPNV from asymptomatic carrier rainbow trout, Salmo gairdneri, Richardson. J. Fish Dis. 5: 285-292

Ahne, W. (1981). Serological techniques currently used in fish virology. In: International symposium on fish biologics: serodiagnostics and vaccines, Leetown, W. Va., USA (S. Karger, Basel). Dev. Biol. Stand. 49: 3-27

Ahne, W., Delventhal, H., Kohlmeyer, V., Thomsen, I. (1986). Nachweis von IPNV-Antikörpern in Forellenseren mit der indirekten Immunofluoreszenztechnik. J. vet. Med. 33: $145-148$

Ahne, W., Thomsen, I. (1986). Infectious pancreatic necrosis: detection of virus and antibodies in rainbow trout IPNVcarrier (Salmo gairdneri). J. vet. Med. 33: 552-554

Ahne, W., Vestergaard-Jørgensen, P. E., Olesen, N. J., Schafer, W. Steinhagen, P. (1986). Egtved virus: occurrence of strains not clearly identifiable by means of virus neutralization tests. J. appl. Ichthyol. 4: 187-189

Amend, D. F., Wedemeyer, G. (1970). Approved procedure for determining absence of infectious pancreatic necrosis (IPN) virus in certain fish and fish products. FDL-27. Bureau of Sport Fisheries and Wildlife, Washington, D.C.

Amlacher, E., Ude, J. Rudolf, C., Ernst, G. (1980). Direct electron microscopical visualization of the presumptive virus of viral haemorrhagic septicaemia (VHS) in the rainbow trout, Salmogairdneri Richarson, and additional histopathological and haematological observation. J. Fish Dis. 3: 55-62

Amos, K. H. (1985). Procedures for the detection and identification of certain fish pathogens, 3rd edn. Fish Health Section, American Fisheries Society, Corvallis, Oregon

Arakawa, C. K., Deering, R. E., Higman, K. H., Oshima, K. H., O'Hara, P. J., Winton, J. R. (1990). Polymerase chain reaction (PCR) amplification of a nucleoprotein gene sequence of infectious hematopoietic necrosis virus. Dis. aquat. Org. 8: $165-170$

Arnzen, J. M., Ristow, S. S., Hesson, C. P., Lientz, J. (1991). Rapid fluorescent antibody tests for infectious hematopoietic necrosis virus (IHNV) utilizing monoclonal antibodies to the nucleoprotein and glycoprotein. J. aquat. Health 3: 109-113 
Babin, M., Hernandez, C., Sanchez, C., Dominguez, J. (1990). Detección rápida del virus de la necrosis pancreática infecciosa por enzimo-inmuno-adsorción de captura. Med. Vet. 7: $557-560$

Babin, M., Hernandez, C., Sanchez, C., Dominguez, J. (1991). Immunodot assay for detection of IPN virus in organ homogenates. Bull. Eur. Ass. Fish Pathol. 11: 65-67

Basurco B., Coll, J. M. (1989a). Spanish isolates and reference strains of viral haemorrhagic septicaemia virus shown similar protein size patterns. Bull. Eur. Ass. Fish Pathol 9: 92-95

Basurco, B., Coll, J. M. (1989b). Variabilidad del virus de la septicemia hemorrágica viral de la trucha en España. Med Vet. 6: 425-430

Basurco, B., Sanz, F., Marcotegui, M. A., Coll, J. M. (1991) The free nucleocapsids of the viral haemorrhagic septicaemia virus contain two antigenically related nucleoproteins. Archs Virol. 119: 153-163

Baudin, F. L. (1987). IHN in France. Bull. Eur. Ass. Fish Pathol 7: 104

Bernard J. Lecocq-Xhonneux, F., Rossius, M., Thiry, M. E., de Kinkelin, P. (1990). Cloning and sequencing the messenger RNA of the $N$ gene of viral haemorrhagic septicemia virus. J. gen. Virol. 71: 1669-1674

Bovo, G., Giorgetti, G., Jorgensen, P. E. V., Olesen, N. J (1987). Infectious haematopoietic necrosis: first detection in Italy, Bull. Eur. Ass. Fish Pathol. 7: 62-63

Bragg, R. R. Combrimk, M. E. (1987). Immunostaphyloccus protein A (ISPA) test for the identification of infectious pancreatic necrosis virus and viral haemorrhagic septicaemia virus. Bull. Eur. Ass. Fish. Pathol. 7: 32-34

Brunson, R., True, K., Yancey, J. (1989). VHS virus isolated at Makah National Fish Hatchery. Am. Fish. Soc. Fish Health Newsletter 17 (2): 3

Caswell-Reno, P., Reno, P. W., Nicholson, B. L. (1986). Monoclonal antibodies to infectious pancreatic necrosis virus: analysis of viral epitopes and comparison of different isolates. J. gen. Virol. 67: 2193-2205

Caswell-Reno, P., Lipipun, V., Reno, P. W., Nicholson, B. L. (1989). Use of a group-reactive and other monoclonal antibodies in an enzyme immunodot assay for identification and presumptive serotyping of aquatic birnaviruses. J. clin. Microbiol. 27-1924-1929

Chilmonczyk, S. (1977). Stimulations specifiques des lymphocytes de truites arc-en-ciel resistantes a la SHV Bull. off. Int. Epiz. 87. 395-396

Chilmonczyk, S. (1978). Stimulation specifique des lymphocytes de truites arc-en-ciel (Salmo gairdnen) resistantes a la septicemie hemorragique virale. C. r. Acad. Sci., Paris 287 387-389

Cohen, J., Lenoir, G. (1974). Ultrastructure et morphologie de quatre rhabdovirus de poissons. Ann. Rech. Vet. 5 $443-450$

Coll, J. M. (1989). Addition of reducing agents to the peroxidase-o-phenylenediamine buffer reduces background of enzyme immunoassays. Rev. Esp. Fisiol. 45: 41-46

Coll, J. M. (1991a). Reproducible solid-phase enzyme immunoassays. Immunologia 10: 73-85

Coll, J. M. (1991b). Hybridization of peroxidase labeled DNA probes to microtitre solid-phase bound DNA (HYBREL ISA). Technique 3: 29-32

Cossarini-Durier, M. (1985). Indirect enzyme-linked immunosorbent assay (ELISA) to titrate rainbow trout serum antibodıes against two pathogens: Yersinia ruckeri and Egtved virus. Aquaculture 49: 197-208

Dear, S., Elazhary, M. A. S. Y (1983). Counter immunoelectrophoresis for identification of infectious pancreatic nec- rosis virus after isolation in cell culture. Can. J. Fish. Aquat. Sci. 40: 2200-2203

de Kinkelin, P., Bearzotti, M. (1981). Immunization of rainbow trout against viral hemorrhagic septicaemia (VHS) with a thermoresistant variant of the virus. Dev. Biol. Stand. 49: $431-439$

Deluca, D., Wilson, M., Warr, G. W. (1983). Lymphocyte heterogeneity in the trout, Salmo gairdneri, defined with monoclonal antibodies to IgM. Eur. J. Immunol. 13: $546-551$

Deuter, A., Enzmann, P. J. (1986). Comparative biochemical and serological studies on two fish-pathogenic rhabdoviruses (VHS-V and SVC-V). J. vet. Med. 33: 36-46

Dixon, P. F. (1985). Rapid detection and identification of fish pathogens by the enzyme-linked immunosorbent assay (ELISA) In: Ellis, A. E. (ed.) Fish and shellfish pathology. Academic Press, London, p. 11-16

Dixon, P. F. (1987). Inhibition of infectious pancreatic necrosis virus infectivity by extracts of rainbow trout, Salmo gairdneri, Richarson tissue. J. Fish Dis. 10: 371-378

Dixon, P. F., Hill, B. J. (1983). Rapid detection of infectious pancreatic necrosis virus (IPNV) by the enzyme-linked immunosorbent assay (ELISA). J. gen. Virol. 64: 321-330

Dixon, P. F., Hill B. J. (1984). Rapid detection of fish rhabdoviruses by the enzyme-linked immunosorbent assay (ELISA). Aquaculture 42:1-12

Domínguez, J., Babin, M., Sanchez, C., Hedrick, R. P. (1991). Rapid serotyping of infectious pancreatic necrosis virus by one-step enzyme-linked immunosorbent assay using monoclonal antibodies. J. virol. Methods 31: 93-104

Domínguez, J., Hedrick, R. P., Sánchez-Vizcíano, J. M. (1990). Use of monoclonal antibodies for detection of infectious pancreatic necrosis virus by the enzyme-linked immunoasorbent assay (ELISA). Dis. aquat. Org. 8: $157-163$

Dorson, M., Torchy, C. (1979). Complement dependent neutralization of Egtved virus by trout antibodies. J. Fish Dis. 2 345-347

Dorson, M., Torchy, C., Michel, C. (1979). Rainbow trout complement fixation used for titration of antibodies against several pathogens. Ann. Rech. vet. 10: 529-534

Duncan, R, Nagy, E., Krell, P. J., Dobos, P. (1987). Synthesis of the infectious pancreatic necrosis virus polyprotein, detection of a virus-encoded, and fine structure mapping of genome segment A coding regions. J. Virol. 61: 3655-3664 EC (1990). European Community Document No. L 276/37

Engelking, H. M., Harry, J. B., Leong, J. C. (1991). Comparjson of representative strains of infectious haematopoietic necrosis virus by serological neutralization and cross-protection assays. Appl environ. Microbiol. 57: 1372-1378

Enzmann, P. J. (1981). Rapid identification of VHS-virus from trout by inmunofluorescence. Dev. Biol. Stand. 49: 57-62

Enzmann, P. J., Maier, B., Bigott, K. (1981). Biochemical data on the RNA of VHS-V and RVC indicating a possible serological relationship. Bull. Eur Ass. Fish Pathol. 1 $37-39$

Estepa, A., Basurco, B., Sanz, F., Coll, J. M. (1991a). Stimulation of adherent cells by the addition of purified proteins of viral haemorrhagic septicaemia virus to trout kidney cell cultures. Viral Immunol 4: 43-52

Estepa, A., Coll, J. M. (1991). Infection of mitogen-stimulated trout leucocytes with salmonid viruses. J. Fish Dis, 14 $555-562$

Estepa, A., Coll, J. M. (1992). In vitro Immunostimulants for optimal responses of kidney cells from healthy trout and from trout surviving viral heamorrhagic septicaemia virus disease. Fish Shellfish Immunol. 2: 53-68 
Estepa, A., Frias, D., Coll, J. M. (1991b). Infection of trout kidney cells cultured in fibrin clots with infectious pancreatic necrosis and viral haemorrhagic septicaemia viruses. Bull. Eur. Ass. Fish Pathol. 11. 101-104

Evans, D. L., Smith, E. E., Brown, F. C. (1987). Nonspecific cytotoxic cells in fish (Ictalurus punctatus) VI. Flow cytometric analysis. Dev. comp. Immunol. 11: 95-104

Faisal, M., Ahne, W. (1980). Use of the immunoperoxidase technique for detection of fish virus antigens. In: Ahne, W. (ed.) Fish diseases. Springer-Verlag, Berlin, p. 186-192

Fijan, N. N., Giorgetti, G. (1978). Infectious pancreatic necrosis isolation of virus from eyed eggs of rainbow trout Salmo gairdneri Richardson. J. Fish Dis. 1: 269-270

Finlay, J., Hill, B. J. (1975). A multiple homogenizer for the rapid preparation of samples for immunoassays and electrophoresis. Biochem. Genet. 25: 47-48

French-Constant, R. H., Devonshire, A. L. (1987). A multiple homogenizer for the rapid preparation of samples for immunoassays and electrophoresis. Biochem. Genet. 25: $47-48$

Ghittino, P., Fijan, N., de Kinkelin, P. (1980). Control methods for major viral diseases of fish in Europe. Bull. off. Inst. Epiz. 92: 967-978

Gilmore, R. D., Leong, J. C. (1988). The nucleocapsid gene of infectious hematopoietic necrosis virus, a fish rhabdovirus. Virology 167: 644-648

Habashi, Y., Schlortfeldt, H. J., Frost, J. W. (1975). Production of antisera against the virus of viral haemorrhagic septicaemia (VHS) of rainbow trout. Zbl. Veterinärmed. 22: $666-672$

Hattori, M., Kodama, H., Ishiguro, S., Honda, A., Mikami, T., Izawa. H. (1984). In vitro and in vivo detection of infectious pancreatic necrosis virus in fish by enzyme-linked immunosorbent assay. Am. J. vet. Res. 45: 1876-1879

Hill, B., Way, K. (1980). Properties and interrelationship of bisegmented double-stranded RNA viruses of fish and shellfish. Proceedings of the conference on aquatic animal viruses, Paris, p. 22-24

Hill, B., Way, K. (1983). Serological classification of fish and shellfish birnaviruses (abstract). First international conference of the Association of Fish Pathologists, Plymouth, p. 10

Hill, B. J., Williams, R. F., Finlay, J. (1981). Preparation of antisera against fish virus disease agents. In: International symposium on fish biologics: serodiagnostics and vaccines, Leetown, W. Va, USA (S. Karger, Basel). Dev. Biol. Stand. 49: $209-218$

Hopper, K. (1989). The isolation of VHSV from salmon at Glenwood Springs, Orcas Island, Washington. Am. Fish. Soc. Fish Health Newsletter 17 (2): 1

Hsu, Y L., Chiang, S. Y., Lin, S. T., Wu, J. L. (1989). The specific detection of infectious pancreatic necrosis virus in infected cells and fish by the immunodot blot method. J.Fish Dis. 12: 561-571

Hsu, Y. L., Leong, J. C. (1985). A comparison of detection methods for infectious haemopoietic necrosis virus. J. Fish Dis. 8: 1-12

Ishiguro, S., Izawa, H., Kodama, H., Onuma, M., Mikami, T. (1984). Serological relationships among five strains of infectious pancreatic necrosis virus. J. Fish Dis. 7: 127-135

Jimenez de la Fuente, J., Marcotegui, M. A., San Juan, M., Basurco, B. (1988). Diagnosis of viral diseases in salmonid farms in Spain. Bull. Eur. Ass. Fish. Pathol. 271: 3-4

Kimura, T., Yoshimizu, M., Yasuda, H. (1984). Rapid, simple serological diagnosis of infectious pancreatic necrosis by coagglutination test using antibody-sensitized staphylococci. Fish Pathol. 19: 25-33
Lannan, C. N., Winton, J. R., Fryer, J. L. (1984). Fish cell lines: establishment and characterization of nine cell lines from salmonids. In Vitro 20: 671-676

Le Berre, M., de Kinkelin, P., Metzger, A. (1977). Identification serologique des rhabdovirus des salmonides. Bull. off. Int. Epiz. 87: 391-393

Lehmann, J., Mock, D., Sturenberg, F. J. (1990). A simplification of the immunofluorescence test in disposable plastic trays for demonstrating the Egtved-and IPN-virus in tissue cultures. Bull. Eur. Ass. Fish Pathol. 10: 44-45

Lilipun, V., Caswell-Reno, P., Hsu, Y. L., Wu, J. L., Tung, M. C., Reno, P. W., Waltanavijarn, W., Nicholson, B. L. (1989). Antigenic analysis of asian aquatic birnavirus isolates using monoclonal antibodies. Fish Pathol. 24: 155-160.

Lorenzen, N., Olesen, N. J., Vestergaard-Jørgensen, P. E. (1988). Production and characterization of monoclonal antibodies to four Egtved virus structural proteins. Dis. aquat. Org. $4: 35-42$

Lorenzen, N., Olesen, N. J., Vestergaard-Jørgensen, P. E. (1990). Neutralization of Egtved virus pathogenicity to cell cultures and fish by monoclonal antibodies to the viral $G$ protein. J. gen. Virol. 71: 561-567

Lowe, T., Sharefkin, J., Yan, S. Q., Dieffenbach, C. W. (1990). A computer program for selection of oligonucleotide primers for polymerase chain reactions. Nucleic Acids Res. 18: $1757-1761$

McAllister, P. E., Fryer, J. L., Pilcher, K. S. (1984), An antigenic comparison between infectious hematopoietic necrosis virus (OSV strain) and the virus of haemorrhagic septicaemia of rainbow trout (Salmo gairdneri) (Denmarck strain) by cross-neutralization. J. Wildl. Dis. 10: 101-103

McAllister, P. E., Owens, W. J. (1987). Identification of the three serotypes of viral haemorrhagic septicaemia virus by imunoblot assay using antiserum to serotype F1. Bull. Eur. Ass. Fish Pathol. 7: 90-91

McAllister, P. E., Schill, W. B. (1986). Immunoblot assay: a rapid and sensitive method for identification of salmonid fish viruses. J. Wildl. Dis. 22: 468-474

McDonald, R., Gower, D. (1981). Genomic and phenotypic divergence among serotypes of aquatic Birnaviruses (infectious pancreatic necrosis virus). Virology 114 : 187-195

McIntosh, K., Wiffert, C., Chernesky, M., Plotkin, S., Mattheis, M. J. (1980). New and useful techniques in rapid viral diagnosis. J. infect. Dis. 142: 793-802

Meier, W., Vestergaard-Jørgensen, P. E. (1975). A rapid and specific method for the diagnosis of viral haemorrhagic septicaemia (VHS). Riv. ital. Pisic. Ittiopat. 1: 11-18

Menezes, J. (1977). Septicemie hemorrhagique virale de la truite arc-en-ciel: etude critique de la tecnique de diagnostic. Bull. off. Int. Epiz. 87: 383-390

Mourton, C., Bearzotti, M., Piechaczyk, M., Paolucci, F., Pau, B., Bastide, J. M., de Kinkelin, P. (1990). Antigenic-capture ELISA for viral haemorrhagic septicaemia virus serotype I. J. virol. Methods 29: 325-334

Mulcahy, D., Batts, W. N. (1987). Infectious hematopoietic necrosis virus detected by separation and incubation of cells from salmonid cavity fluid. Can. J. Fish. Aquat. Sci. 44: 1071-1075

Mulcahy, D., Pascho, R. J., Jenes, C. K. (1983). Titre distribution patterns of infectious haematopoietic necrosis virus in ovarian fluids of hatchery and feral salmon populations. J. Fish Dis. 6: 183-188

Neukirch, M. (1984a). An experimental study of the entry and multiplication of viral haemorrhagic septicaemia virus in rainbow trout, Salmo gairdneri Richardson, after waterborne infection. J. Fish Dis. 7: 231-234 
Neukirch, M. (1984b). Some aspects of virus shedding by rainbow trout (Salmo gairdneri, Rich.) after waterborne infection with viral haemorrhagic septicaemia (VHS) virus. Zbl. Bakt. Parasitkde. 257: 433-438

Nicholson, B. L., Caswell, P. (1982). Enzyme-linked immunosorbent assay for identification of infectious pancreatic necrosis virus. J. clin. Microbiol. 16: 469-472

Nicholson, B. L., Henchal, E. A. (1978). Rapid identification of infectious pancreatic necrosis virus in infected cell cultures by immunoperoxidase techniques. J. Wildl. Dis. 14: $465-469$

Nicholson, B., Pochebit, S. (1981). Antigenic analysis of infectious pancreatic necrosis viruses (IPNV) by neutralization kinetics. Dev. Biol. Stand. 49: 35-41

Nishimura, T., Ishida, Y., Yamamoto, S., Fukuda, H., Okamoto, N., Sano, T (1988). Infectious haematopoietic necrosis: virus titre in the fish bodies, rearing water and feces of artificially infected rainbow trout fry. Fish Pathol. 23: $13-17$

Okamoto, N., Hedrick, R. P., Fryer, J. L., Sano, T (1983). Antigenic relationships of selected strains of infectious pancreatic necrosis virus (IPNV) and European eel virus. J. Fish Dis. 6: 19-25

Olberding, K. P., Frost, J. W. (1975). Electron microscopical observations of the structure of the virus of viral haemorrhagic septicaemia (VHS) of rainbow trout (Salmo gairdneri). J. gen. virol. 27: 305-312

Olesen, N. J., Lorenzen, N., Vestergaard-Jørgensen, P. E. (1991). Detection of rainbow trout antibody to Egtved virus by enzyme-linked immunosorbent assay (ELISA), immunofluorescence (IF) and plaque neutralization test (50\% PNT). Dis. aquat. Org. 10: $31-38$

Olesen, N. J., Vestergaard-Jørgensen, P. E. (1986). Detection of neutralizing antibody to Egtved virus in rainbow trout (Salmo gairdneri) by plaque neutralization test with complement addition. Appl. Ichthol. 2: 33-41

Piper, D., Nicholson, N. L., Dunn, J. (1973). Immunofluorescent study of the replication of infectious pancreatic necrosis virus in trout and Atlantic salmon cell cultures. Infection Immunity 8: 249-254

Ristow, S. S., Arnzen, J. M. (1989). Development of monoclonal antibodies that recognize a type-2 specific and a common epitope on the nucleoprotein of infectious hematopoietic necrosis virus. J. aquat. Anim. Health 1. 119-125

Ristow, S. S., Arnzen, J. M. (1991). Monoclonal antibodies to the glycoprotein and nucleoprotein of infections hematopoietic necrosis virus (IHNV) reveal differences among isolates of the virus by fluorescence, neutralization and electrophoresis. Dis. aquat. Org. 11. 105-115

Rodak, L., Pospisil, Z., Tomanek, J., Vesely, T., Obr, T., Valicek, L. (1988). Enzyme-linked immunosorbent assay (ELISA) detection of infectious necrosis virus (IPNV) in culture fluids and tissue homogenates of the rainbow trout Salmo gairdneri, Richardson. J. Fish. Dis. 11: 225-235

Saint-Jean, S. R., Vilas, M. P. M., Angel, M. P., Perez, S. P. (1991). Detection of infectious pancreatic necrosis in a carrier population of rainbow trout, Oncorhynchus mykiss (Richardson), by flow cytometry. J. Fish Dis. 14: 545-553

Sánchez, C, Coll, J. M., Dominguez, J. (1991). One step purification of rainbow trout immunoglobulin. Vet. Immunol. Immunopathol. 27: 383-392

Sánchez, C., Dominguez, J., Coll, J. (1989). Immunoglobulin heterogeneity in the rainbow trout, Salmo gairdneri Richardson. J. Fish Dis. 12: 459-465

Sánchez, M. C. T. Coll, J. M. (1989). La estructura de las inmunoglobulinas de peces. Inmunologia 8: 47-54
Sanz, F., Coll, J. M. (1990). Mayor eficacia y sensibilidad en el diagnóstico de rabdovirus. Biotecnologia, 6: 7-9

Sanz, F., Coll, J. M. (1991a). Diagnóstico de la septicemia hemorrágica viral de los salmónidos. Veterinaria Praxis 6: 25-32

Sanz, F., Coll, J. M. (1991b). Detection of hemorrhagic septicemia virus of salmonid fishes by use of an enzyme linked immunosorbent assay containing 2 non competituve monoclonal antibodies against early viral nucleoproteins and high sodium cloride concentration. Am. J. vet. Res. (in press)

Schultz, C. L., Lidgerding, B. C., McAllister, P. E., Hetrick, F. M. (1985). Production and characterization of monoclonal antibody against infectious hematopoietic necrosis virus. Fish Pathol 20: 339-341

Schultz, C. L., McAllister, P. E., Schill, W. B., Lidgerding, B. C., Hetrick, F. M. (1989). Detection of infectious haemotopoietic necrosis virus in cell culture fluid using immunoblot assay and biotinylated monoclonal antibody. Dis. aquat. Org. $7: 31-37$

Shors, S. T., Winston, V (1989). Neutralizing antibodies for infectious hematopoietic necrosis virus in eggs of steelhead trout (Salmo gairdnerI). Am. J. vet. Res. 50: 232-234

Sobrino, F., Escribano, J. M., Coll, J. M. (1989). Diagnostico de virus por amplificación específica y deteccion no radioactiva. Biotecnología 5: 8-10

Swanson, R. N., Gillespie, J. H. (1981). An indirect fluorescent antibody test for the rapid detection of infectious pancreatic necrosis virus. J. Fish Dis. 4: 309-315

Thuvander, A., Fossum, C., Lorenzen, N. (1990). Monoclonal antibodies to salmonid immunoglobulin: characterization and applicability in immunoassays. Dev. comp. Immunol. 14: $415-423$

Vestergaard-Jørgensen, P. E. (1968). Serological identification of Egtved virus (virus of viral haemorrhagic septicaemia of rainbow trout). A preliminary report. Bull. off. Int. Epiz. 69: 985-989

Vestergaard-Jørgensen, P. E. (1971). Egtved virus: demonstration of neutralizing antibodies in serum from artificially infected rainbow trout (Salmo gairdnerl). J. Fish. Res. Bd Can. 28: 875-877

Vestergaard-Jørgensen, P. E. (1972). Egtved virus: antigenic variation in 76 virus isolates examined in neutralization test and by means of the fluorescent antibody technique. Symp. Zool. Soc. Lond. 30: 333-339

Vestergaard-Jorgensen, P. E. (1973). The nature and biological activlty of IPN virus neutralizing antibodies in normal and immunized rainbow trout (Salmo gairdnern). Archiv gesamte Virusforsch. 42: 9-20

Vestergaard-Jørgensen, P. E. (1974). Indirect fluorescent antibody techniques for demonstration of trout viruses and corresponding antibody. Acta vet. scand. 15: 198-205

Vestergaard-Jørgensen, P. E., Meyling, A. (1972). Egtved virus: demonstration of virus antigen by the fluorescence antibody technique in tissue of rainbow trout affected by viral haemorrhagic septicaemia and in cell cultures infected with Egtved virus. Archiv. gesamte Virusforsch. 36: $115-122$

Way, K. Dixon, P. F. (1988). Rapid detection of VHS and IHN viruses by the enzyme-linked immunosorbent assay (ELISA). J. appl. Ichthyol. 4: 182-189

Winton, J. R. (1991). Recent advances in detection and control of infectious hematopoietic necrosis virus in aquacuiture. Ann. Rev. Fish Dis. 1: 83-93

Winton, J. R., Arakawa, C. K., Lannan, C. N., Fryer, J. L. (1988). Neutralizing monoclonal antibodies recognize antigenic variants among isolates of infectious hematopoietic necrosis virus. Dis aquat. Org. 4: 199-204 
Wolf, K., Mann, J. A. (1980). Poikilothermic vertebrate cell lines and viruses. A current listing for species. In Vitro 16: 168-169

Wolski, S. C., Roberson, B. S., Hetrick, F. M. (1986). Monoclonal antibodies to the Sp strain of infectious pancreatic necrosis virus. Vet. Immunol. Immunopathol. 12: 373-381 Yoshimizu, M., Kimura, T (1985). A coagglutination test with

Responsible Subject Editor: D. E. Hinton, Davis, California, USA antibody-sensitized staphylococci for rapid and simple diagnosis of bacterial and viral diseases of fish. Fish Pathol. 20: $234-261$

Zwillenberg, L. O., Jensen, M. H., Zwillenberg, H. H. L. (1965). Electron microscopy of the virus of viral haemorrhagic septicaemia of rainbow trout (Egtved virus). Arch. gesamte Virusforsch. 17: 1-19

Manuscript first received: July 15, 1991 Revised version accepted: May 5, 1992 